Portland State University

PDXScholar

\title{
A Survey of Native Bees and Their Floral Use in Portland's Urban Orchards
}

Diandra L. Diamond

Portland State University

Follow this and additional works at: https://pdxscholar.library.pdx.edu/honorstheses

Part of the Animal Sciences Commons Let us know how access to this document benefits you.

\section{Recommended Citation}

Diamond, Diandra L., "A Survey of Native Bees and Their Floral Use in Portland's Urban Orchards" (2020). University Honors Theses. Paper 912.

https://doi.org/10.15760/honors.933

This Thesis is brought to you for free and open access. It has been accepted for inclusion in University Honors Theses by an authorized administrator of PDXScholar. Please contact us if we can make this document more accessible: pdxscholar@pdx.edu. 
A Survey of Native Bees and their Floral Use in Portland's Urban Orchards

by

\title{
Diandra Diamond
}

An undergraduate honors thesis submitted in partial fulfillment of the

\author{
requirements for the degree of \\ Bachelor of Science \\ in \\ University Honors \\ and \\ Biology
}

Thesis Advisor

Dr. Susan E. Masta

Portland State University 


\section{Contents}

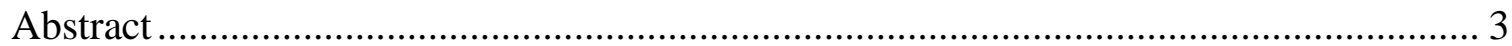

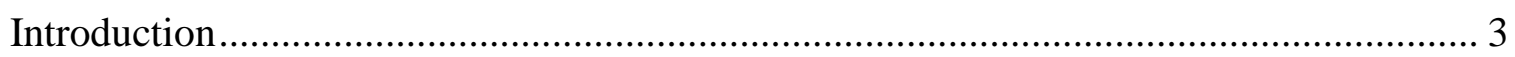

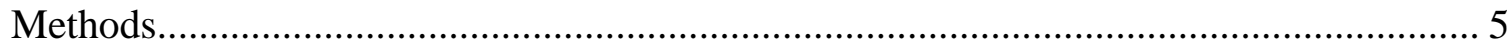

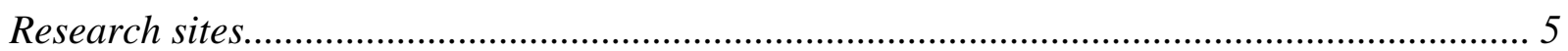

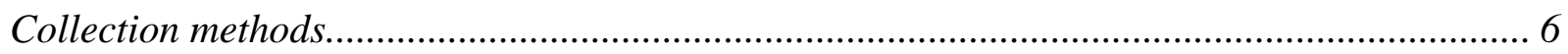

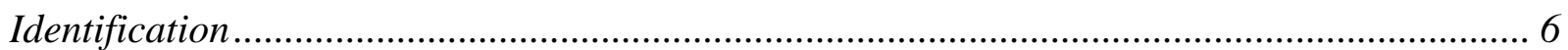

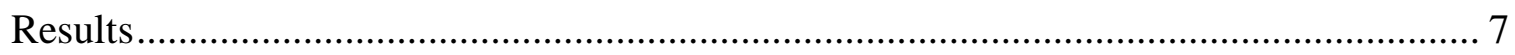

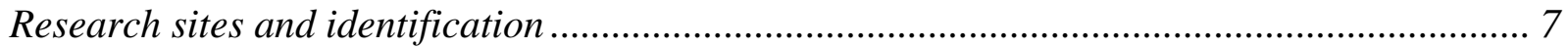

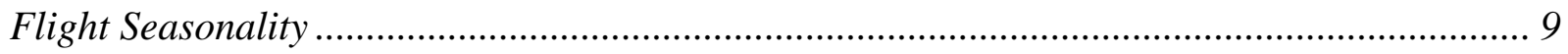

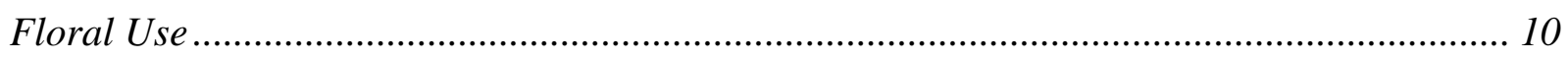

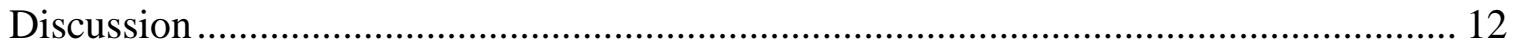

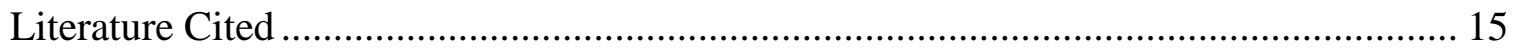




\begin{abstract}
Native bees are all around us, yet very few surveys have been performed on which bees reside in Portland, Oregon. For this honors thesis, native bees collected from two urban orchards and one botanical garden located in eastern Portland in 2018 and 2019 were identified to genus or to species, and their floral use recorded. This data will become part of the ongoing native bee survey being performed by Susan Masta's laboratory and the Museum of Natural History at Portland State University. The bees that were most commonly collected included Ceratina spp. $(\mathrm{n}=42)$, Andrena spp. $(\mathrm{n}=34)$, Halictus spp. $(\mathrm{n}=29)$, and Bombus spp. $(\mathrm{n}=21)$. Observations made during these collections suggest that a diversity of floral resources, but especially ornamental plants within Asteraceae, Rosaceae, and Boraginaceae (notably genera Erigeron, Symphyotrichum, Fragaria, and Pentaglottis) may support a wide diversity of native bees in an urban or suburban orchard setting over the greatest proportion of native bee flight seasons.
\end{abstract}

\title{
Introduction
}

Wherever angiosperms can be found flowering, there will most certainly be a variety of native bees close by, be they actively foraging, pollinating, or nesting hidden from sight. Oregon is home to a great diversity of these native bees, at an estimated 500 species, which perform valuable pollination services for gardens, agricultural crops, meadows, and natural areas (Broussard et al., 2011; Gonzalez et al., 2013; Kimoto et al., 2012; Rao \& Stephen, 2010). Native bees have varying floral preferences, seasonality, and habits evolved to best take advantage of the breadth of resources present during their short adult lives. Most native bees from the families Andrenidae, Halictidae, and Colletidae nest underground, with Megachilidae and some Apidae nesting from within pithy stems or wooden cavities bored by beetles. Unlike the European honeybee (Apis mellifera), native bees are overwhelmingly solitary, meaning adult 
females must forage for pollen in order to provide directly for their own brood (Michener 2007). Because of this, native bees have evolved associations with flowering angiosperms accessible during their flight season. Many bees have formed specialist associations to a particular plant family or morphology, while others can be considered floral generalists that access the widest range of available floral sources (Cane, 2018; Cane \& Love, 2016).

Although native bee biodiversity is rich, it is not immune from the dangers of habitat loss that plague both urban areas and agricultural areas. Of the factors that have been established as the main causes for bee decline: habitat fragmentation, climate change, agriculture and pesticides; habitat fragmentation and loss have been recognized as the most threatening to native bees (Potts et al. 2010; Winfree et al., 2009). Although of course native bees have always pollinated the native plants they have coevolved with, there is increasing evidence that native bees may perform a greater share of pollination services for human crops when compared to the honeybee. To lose native bees would mean to disrupt plant-pollinator interactions and phenology that have evolved over hundreds of thousands of years, which would have compounding effects on the environment as well as economy (Boggs \& Inouye 2012; Willmer 2012).

No systematic surveys have been performed on what species of native bees are found in Oregon, let alone Portland specifically - presenting a need for this type of biological survey. Considering that urban environments may be at risk for pollinator decline due to habitat loss, there is a unique opportunity to fill a gap in knowledge on Portland, Oregon's native bees and their floral usage. Urban orchards and the bees that pollinate them are important to study for their role in providing food to these habitats. For this Honors thesis, I participated in an ongoing survey of Portland's native bees, which included collecting, identifying, and analyzing bees and 
their floral use from a number of sites in Portland - focusing most specifically on integrating collections from 2018 and 2019 from two orchards and one botanical garden into the survey.

\section{Methods}

Research sites

Three sites were selected for their proximity to local orchards and one botanical garden in Portland, Oregon by PSU's alum Jess Tyler during his master's thesis work on citizen science. The three sites were located in eastern Portland, each with varying layouts. Parkrose Community Orchard is organized stringently, with structured rows of fruit trees as opposed to natural spacing. Sabin Community Orchard, however, is organized far less intentionally. Both orchards are surrounded with other plants both native and non-native, to serve the environment as well as for aesthetic value, on which most collections were performed. Although not being an orchard, Leach Botanical Garden was selected for its similarly wide diversity of flora.

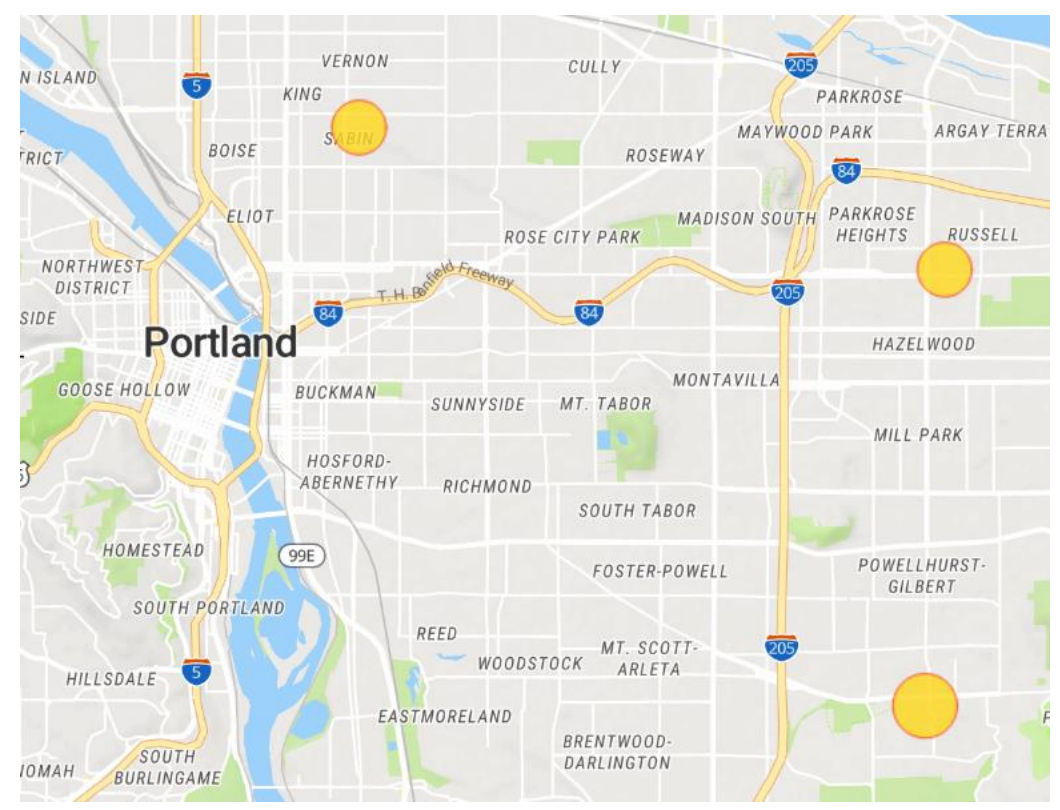

Figure 1. Map displaying all the three Orchard native bee survey locations. Clockwise from top: Sabin Community Orchard, Parkrose Community Orchard, Leach Botanical Garden. 


\section{Collection methods}

Collections occurred between the months of March and September of 2018 and 2019 at regular intervals. The sampling process involved hand or net collection, as opposed to blue-vane, bowl, or pan traps - which are known to over sample Halictidae (Griswold 2008). By using hand collection techniques, the sampling method was more conservative, removing fewer specimens from the environment. By hand netting each bee, we were able to record precisely what flower it was visiting at the time it was collected. Upon collection, each bee was placed into a plastic vial.

Labels were added into each vial highlighting coordinates of the site, floral use or association, as well as current date. In the case of no floral association, bees were labeled with "none" or a description of their behavior, such as "hovering over ground". Bees were then frozen to euthanize, pinned to show identifying features, and sterilized in a $-80^{\circ} \mathrm{C}$ freezer before being stored in airtight drawers in invertebrate collections at Portland State University's Museum of Natural History.

\section{Identification}

Once stored, bees were retrieved and identified based on differentiable characteristics. Many taxa are able to be identified to the species level, while others are only identifiable to genus or morphospecies, such as Andrena, many Osmia, and Lasioglossum. Published keys were used to achieve the lowest possible level of identification for each individual. Bees were first identified to genus using August Jackson's “The Bees of the Willamette Valley" as well as The Bee Genera of North and Central America (Hymenoptera: Apoidea) (Michener, McGinley, and Danforth, 1994). Afterwards, bees were identified to species using Bees of the Genus Ceratina in 
America North of Mexico by Daly (1973), Leafcutter and Mason Bees of the Genus Megachile Latreille (Hymenoptera: Megachilidae) in Canada and Alaska by Sheffeild et al. (2011), Bees of Northwestern America: Halictus (Hymenoptera: Halictidae), as well as Bees of Northwestern America: Agapostemon (Hymenoptera: Halictidae), by Roberts (1973).

Features used to identify bees to their lowest level are recognizable only by microscopic inspection, and involve relative measurements between features such as the ocelli, mandibles, antennae, sub-antennal sutures, and propodeal triangles as seen under a dissecting microscope. Other features include variants of integument hue and texture, number of sub-marginal cells in wing venation, abdominal hair banding, presence of axillae, facial fovea, facial markings, antennal length, and many other lines and landmarks found on the integument of bees. The identification of bees from Sabin Community Orchard, Leach Botanical Garden, and Parkrose Community Orchard were preliminarily performed by Jess Tyler in 2018 and 2019, but many taxa were checked for species identification accuracy, or identified to species for the purposes of this survey.

\section{Results}

Research sites and identification

In total, 234 specimens were sampled from Sabin, Leach, and Parkrose between the months of March and September of 2018 and 2019, supplementing the previously collected bees from the main study's industrial, urban, and residential sites (Table 1). From Sabin Community Orchard a total of 56 individuals were collected, from Parkrose Community Orchard 64 individuals were collected, and from Leach Botanical Garden 127, making it the most sampled 
site of the three. Taxa that had not previously been found in other locations in Portland include the genus Dianthidium and Colletes.

Table 1. Counts of all bees collected from Parkrose Community Orchard, Sabin Community Orchard, and Leach Botanical Garden, identified to the level of genus.

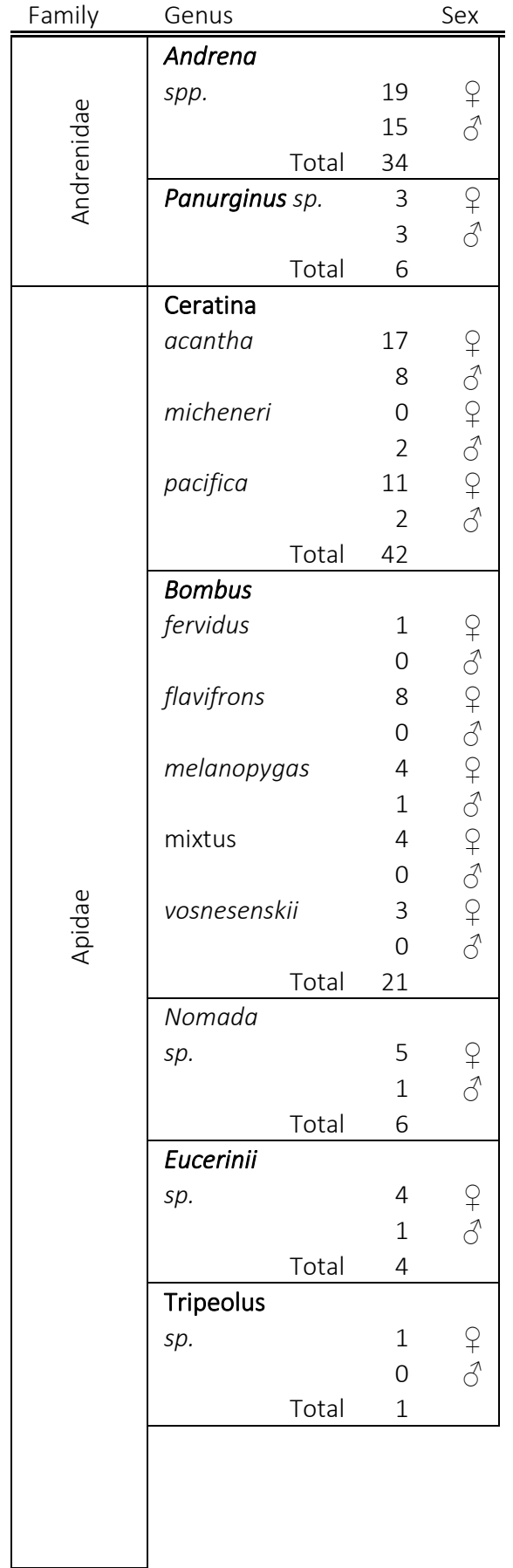

\begin{tabular}{|c|c|c|c|}
\hline Family & Genus & & Sex \\
\hline \multirow{34}{*}{ 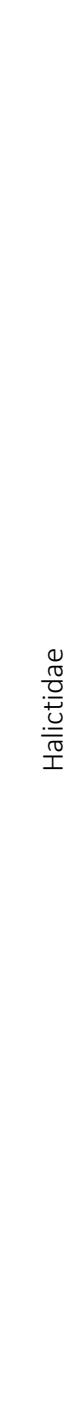 } & \multicolumn{3}{|l|}{ Halictus } \\
\hline & \multirow[t]{2}{*}{ confusus } & 4 & q \\
\hline & & 0 & 3 \\
\hline & \multirow[t]{2}{*}{ ligatus } & 5 & o \\
\hline & & 4 & 3 \\
\hline & \multirow[t]{2}{*}{ rubicundus } & 1 & q \\
\hline & & 0 & 0 \\
\hline & tripartitus & 12 & q \\
\hline & \multirow{2}{*}{ virgatellus } & 1 & $\begin{array}{l}0 \\
0\end{array}$ \\
\hline & & 1 & + \\
\hline & \multirow{2}{*}{$s p$. } & 1 & 0 \\
\hline & & 0 & 3 \\
\hline & Total & 29 & \\
\hline & \multirow{3}{*}{$\begin{array}{l}\text { Lasioglossum } \\
\text { sp. }\end{array}$} & & \\
\hline & & 18 & q \\
\hline & & 1 & ठ \\
\hline & Total & 19 & \\
\hline & \multicolumn{2}{|l|}{ Agapostemon } & \\
\hline & \multirow{2}{*}{ coloradinus } & 2 & q \\
\hline & & 0 & 0 \\
\hline & \multirow[t]{2}{*}{ femoratus } & 2 & q \\
\hline & & 0 & 3 \\
\hline & \multirow[t]{2}{*}{ sp. } & 1 & q \\
\hline & & 1 & 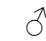 \\
\hline & \multirow[t]{2}{*}{ texanus } & 4 & q \\
\hline & & 0 & 0 \\
\hline & \multirow{2}{*}{ virescens } & 1 & q \\
\hline & & 7 & 3 \\
\hline & Total & 18 & \\
\hline & \multicolumn{2}{|l|}{ Sphecodes } & \\
\hline & $s p$. & 4 & 오 \\
\hline & & 2 & 3 \\
\hline & & 1 & $\mathrm{NI}$ \\
\hline & Total & 7 & \\
\hline \multirow{8}{*}{$\begin{array}{l}\frac{0}{0} \\
\frac{0}{0} \\
\frac{0}{\overline{0}} \\
0\end{array}$} & \multicolumn{2}{|l|}{ Hylaeus } & \\
\hline & \multirow[b]{3}{*}{ Total } & 1 & q \\
\hline & & 4 & 3 \\
\hline & & 5 & \\
\hline & \multicolumn{2}{|l|}{ Colletes } & \\
\hline & $s p$ & 1 & q \\
\hline & & 0 & 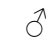 \\
\hline & Total & 1 & \\
\hline
\end{tabular}

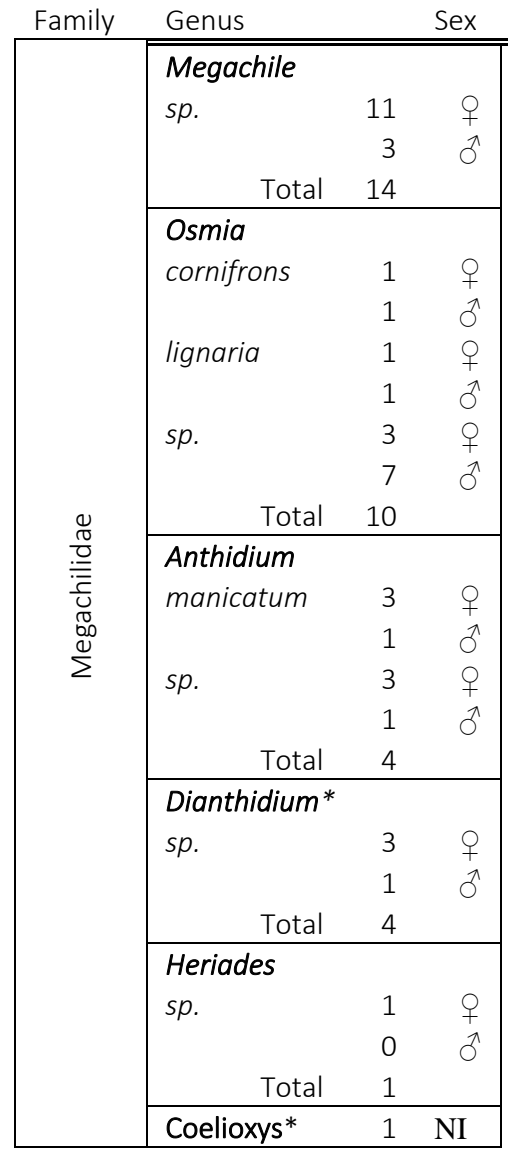


The most frequently collected taxa included Ceratina $(\mathrm{n}=42)$, Andrena $(\mathrm{n}=34)$, and Halictus $(\mathrm{n}=29)$ (Table 1). Ceratina acantha, being the most common species of Ceratina, was the most collected of any individual species, at 25 collections (Table 1).

\section{Flight Seasonality}

Bees collected from all three sites were analyzed separately from the urban core of Portland bees. However, flight seasonality data was compiled between the two surveys in order to increase the robustness of previously identified trends. All bees from these additional sites were added into existing genera on the chart, but newly identified taxa were not included due to the low number of individuals that were collected (Table 1). Native bees (excluding bumble bees, which overwinter as adults) were present primarily between the months of March and September, with only one individual of the genus Agapostemon being collected in October. The earliest bees to peak in spring include Andrena, Nomada, and Osmia, followed in the summer by the Halictids, Megachilids, and by Ceratina and Melissodes (Table 2).

Table 2. Flight seasonality chart generated from compilation of collection dates for three years of the native bee survey. Excluded are new genera or genera low in total number of collections.

\begin{tabular}{|c|c|c|c|c|c|c|c|c|c|}
\hline Family & Genus & March & April & May & June & July & Aug. & Sept. & Oct. \\
\hline \multirow[b]{2}{*}{ Andrenidae } & Andrena & 22 & 54 & 34 & 25 & 1 & & & \\
\hline & Panurginus & & & 35 & 7 & 1 & & & \\
\hline \multirow{3}{*}{ Apidae } & Ceratina & 7 & 11 & 31 & 29 & 13 & 44 & 20 & \\
\hline & Eucerinii & & 1 & 4 & 5 & 18 & 29 & 6 & \\
\hline & Nomada & 1 & 20 & 15 & 4 & 1 & & & \\
\hline \multirow[t]{2}{*}{ Colletidae } & Hylaeus & & & 5 & 12 & 16 & 8 & 9 & \\
\hline & Agapostemon & & & 6 & 6 & 8 & 13 & 21 & 1 \\
\hline \multirow{2}{*}{ Halictidae } & Halictus & 2 & 8 & 10 & 22 & 34 & 29 & 6 & \\
\hline & Lassioglossum & 2 & 3 & 17 & 27 & 35 & 20 & 20 & \\
\hline \multirow{4}{*}{ Megachilidae } & Anthidium & & & 4 & 14 & 15 & 12 & 3 & \\
\hline & Heriades & & & & 4 & 10 & 3 & & \\
\hline & Meraphilo & & & 2 & 9 & 24 & 14 & 1 & \\
\hline & Osmia & 20 & 33 & 16 & 8 & 4 & & & \\
\hline
\end{tabular}


Floral Use

Table 3. Number of collection events on each floral family and genus. Most visited, recommended genera are bolded.

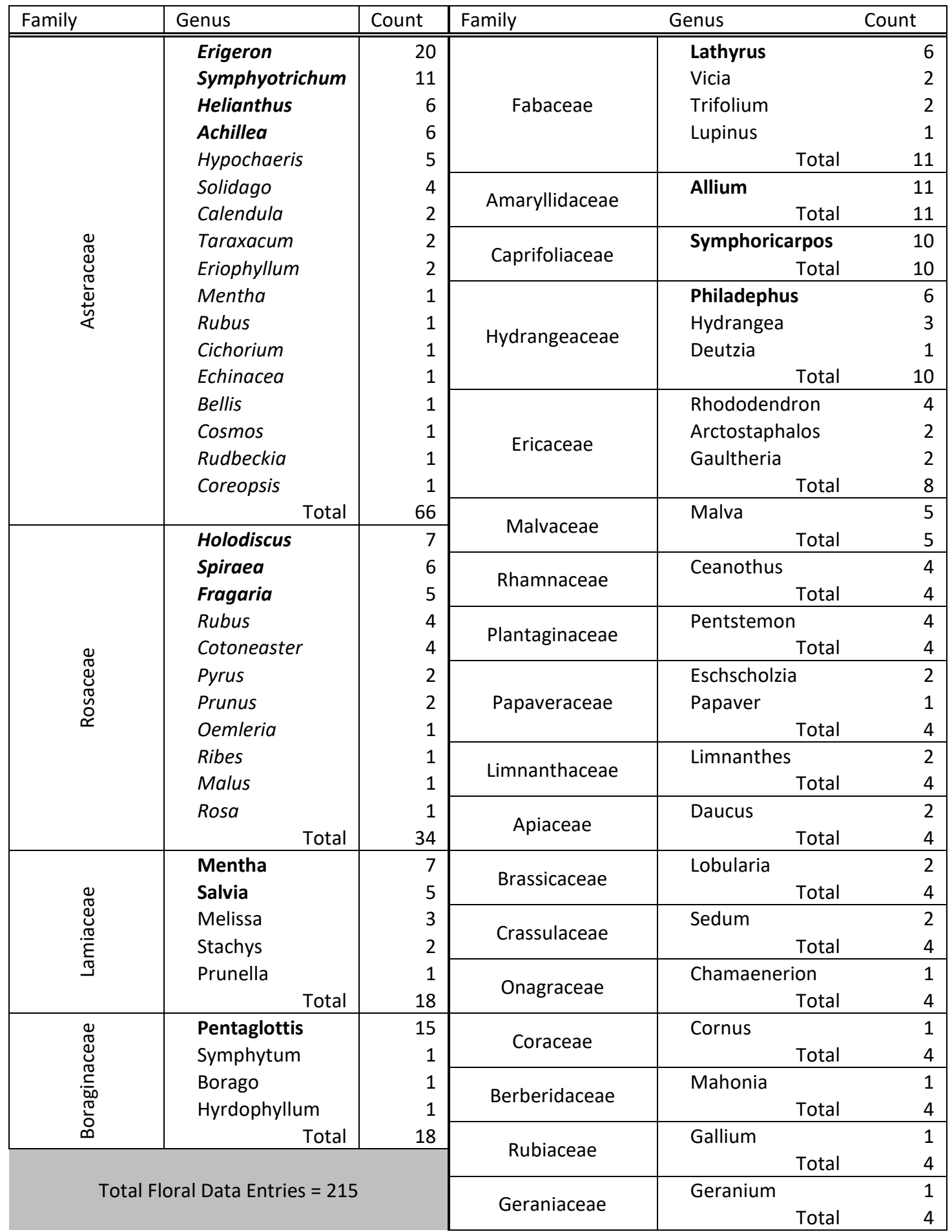


In total, 215 native bees were found on 64 plant genera. Floral families Asteraceae,

Rosacae, Boraginacae, and Lamiaceae were all among the most commonly visited by native bees

(Table 3). Asteraceae $(\mathrm{n}=66)$, represented $28.7 \%$ of total collections - Erigeron,

Symphyotrichum, and Achillea were most frequently sampled on. Rosaceae $(\mathrm{n}=34)$, represented

$14.9 \%$ of bees collected - Holodiscus, Fragaria., Spiraea were most common. Likewise,

Boraginaceae $(\mathrm{n}=18)$ made up $8 \%$ of collections, of which 15 were Pentaglottis sempervirens.

Lamiaceae $(n=18)$ also made up $8 \%$, of which Mentha arvense, Salvia sp., and Melissa

officinalis shared similar prevalence.

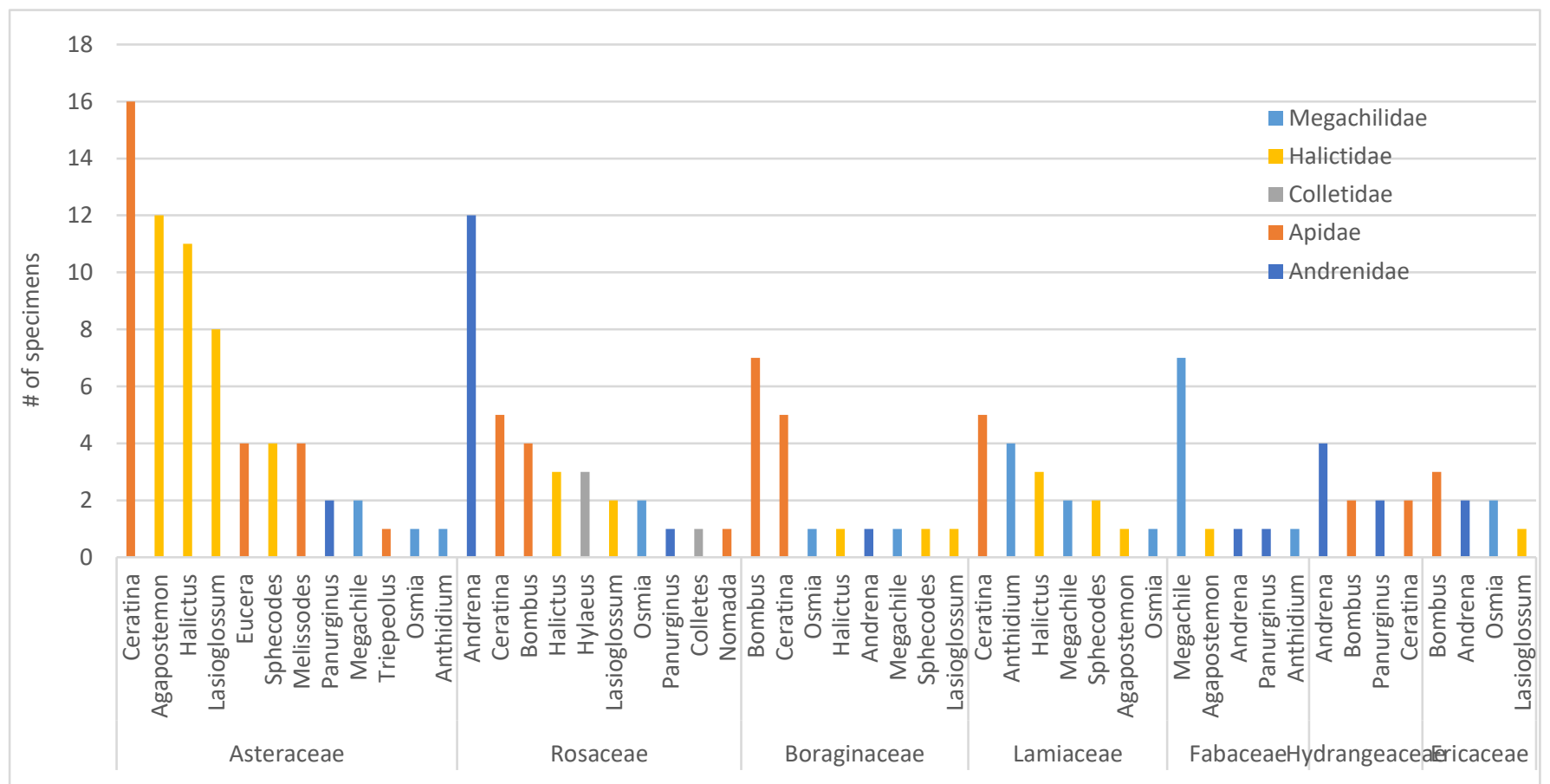

Figure 2. Native bee genera sorted by number of collections and by the most common plant families: Asteraceae, Rosaceae, Boraginaceae, Lamiaceae, Fabaceae, Hydrangeaceae, and Ericaceae 


\section{Discussion}

By combining the three new sites, two orchards and botanical garden, with data from the previous three years of survey, counts were increased for nearly every genus previously identified, with the addition of new discoveries, Dianthidium and Colletes (Table 1). A total of 234 native bees were collected and identified, representing 20 genera. The total number of species present in this sample is unable to be determined due to the inability to identify bees that lack either taxonomic keys or species descriptions, but the Masta Laboratory's surveying in Portland overall has conservatively suggested the number at 104 species, and counting.

Asteraceae, Rosaceae, and Boraginaceae were among the dominant plant families visited, which could potentially be explained by their abundance in urban gardens and orchards (Wojcik \& McBride 2011). In addition, weedy, ornamental plants are some of the most pervasive floral visitation sites, as they flower a majority of the year and are generally attractive to all native bee families (Lowenstein et al. 2018). Even non-native plant species, despite their status, can provide resources for native bees that need support in the form of pollen and nectar during the fringes of flight seasonality.

As we gather more data, we can better determine what flowers native bees use in Portland, keeping in mind that native bees' visitation of certain plants is dependent on floral morphology and seasonality. Bombus spp. and other larger bees have been associated in the literature with flowers with tubular, occluded morphologies such as Fabaceae and Boraginaceae, while smaller bees have been shown to prefer flowers with open, accessible morphologies such as Asteraceae (Roof et al. 2018). These findings were partially substantiated in even the relatively small samples of Portland's urban orchards, as Bombus spp. account for a majority of 
collections on Boraginaceae, while accounting for no collections on Asteraceae (Figure 2). Ceratina spp. appear to be the broadest generalists, being collected on all major floral families except Fabaceae and Ericaceae (Figure 2). When viewed by family however, the data suggests that Halictidae overall have the greatest bias towards Asteraceae. For most bee taxa, plants in the family Asteraceae were the most frequently visited, with Erigeron and Symphyotrichum in particular accounting for $15 \%$ of all collections (Table 3).

As spring bees present between March and June, but most abundant during April (Table 2), Andrena spp. were often collected on Rosaceae. Interestingly, Andrena spp. were never collected on Asteraceae, unlike most other bee genera (Figure 2.) This suggests a phenological association between their flight seasonality and Rosaceae's flowering period, but may well also be due to their floral preference. Fragaria sp. and Malus sp., of the family Rosaceae are some of the most common orchard plants, making their association with Andrena spp. notable in that environmental context, but more study would need to be performed to determine the extent of Andrena's use of Rosaceae.

A way in which this research could potentially be of value is in informing the choices of city planners in their pursuit to improve green spaces. Urban environments have the potential to be havens for wild bees (Hall et al. 2017), as they have been shown to be greater in native bee biodiversity than more rural areas, despite lacking in abundance (Choate et al. 2018, Fortel et al. 2014, Simao 2017). Despite this, cavity nesting bees, notably Osmia, may perform better in urban environments than ground nesting bees, due to the pavement of roads and sidewalks limiting ground space (Cardoso \& Gonçalves 2018). This means that for urban planners and gardeners, there is increased responsibility to make choices that best support the widest possible diversity of native bees, including the provision of ample open ground with permeable surfaces. 
Considering the increase in conservation or sustainability focused attitudes in Portland, there is a genuine interest in pollinator conservation in an urban context. We should be cognizant of providing floral resources that the hard-working and diverse native pollinators can access year-round - their existence, as well as our urban food gardens directly depend upon it. 


\section{Literature Cited}

Boggs, C., \& Inouye, D. (2012). A single climate driver has direct and indirect effects on insect population dynamics. Ecology Letters, 15(5), 502-508.

Broussard, M. (2011). Native Bees, Honeybees, and Pollination in Oregon Cranberries. HortScience, 46(6), 885-888.

Cane JH 2018. Co-dependency between a specialist Andrena bee and its death camas host, Toxicoscorion paniculatum. All PIRU Publications 798.

Cane JH, Love B 2016. Floral guilds of bees in sagebrush steppe: comparing bee usage of wildflowers available for postfire restoration. Natural Areas Journal 36:377-391.

Daly HV 1973. Bees of the genus Ceratina in America North of Mexico (Hymenoptera: Apoidea). University of California Publication in Entomology vol. 74 pp. 17-27.

Desaegher, J., Nadot, S., Fontaine, C., \& Colas, B. (n.d.). Floral morphology as the main driver of flower-feeding insect occurrences in the Paris region. https://doi.org/10.1007/s11252018-0759-5

Gonzalez, N., DeBano, S., Kimoto, C., Taylor, R., Tubbesing, C., \& Strohm, C. (2013). Native Bees Associated with Isolated Aspen Stands in Pacific Northwest Bunchgrass Prairie. Natural Areas Journal, 33(4), 374-383.

Griswold, Terry, Messinger, Olivia J., Wilson, Joseph S, \& Messinger, Olivia J. (2008). Sampling Bee Communities (Hymenoptera: Apiformes) in a Desert Landscape: Are Pan Traps Sufficient? Journal of the Kansas Entomological Society, 81(3), 288-300. 
Hall DM, Camilo GR, Tonietto RK, Ollerton J, Ahrne'K, Arduser M, Ascher JS, Baldock KCR, Fowler R, Frankie G, Goulson D, Gunnarsson B, Hanley ME, Jackson JI, Langellotto G, Lowenstein D, Minor ES, Philpott SM, Potts SG, Sirohi MH, Spevak EM, Stone GN, Threlfall CG 2017. Essay: The city as a refuge for insect pollinators. Conservation Biology 31:24-29

Kimoto, C., Debano, S., Thorp, R., Rao, S., \& Stephen, W. (2012). Investigating temporal patterns of a native bee community in a remnant North American bunchgrass prairie using blue vane traps. Journal of Insect Science, 12, 6.

Lowenstein DM, Matteson KC, Minor ES 2018. Evaluating the dependence of urban pollinators on ornamental, non-native, and 'weedy' floral resources. Urban Systems 22:293-302.

Michener, C., McGinley, Ronald J, \& Danforth, Bryan N. (1994). The bee genera of North and Central America (Hymenoptera:Apoidea). Washington: Smithsonian Institution Press.

Michener CD 2007. The bees of the world (2nd Ed.) The Johns Hopkins University Press. Baltimore, Maryland. pp. 9, 126,185, 227, 223, 260, 304, 335-337, 417, 459, 534, 570, 593-594, 626, 688.

Rao, Sujaya, \& Stephen, W.P. (2010). Abundance and diversity of native bumble bees associated with agricultural crops: The Willamette Valley experience. Psyche (Cambridge, 1874), Psyche (Cambridge, 1874), Annual, 2010.

Roberts RB 1973. Bees of Northwestern America: Agapostemon (Hymenoptera: Halictidae). Oregon State University Agricultural Experiment Station Technical Bulletin No. 125. 
Roof, S. M., DeBano, S., Rowland, M. M., \& Burrows, S. (2018). Associations Between Blooming Plants and their Bee Visitors in a Riparian Ecosystem in Eastern Oregon. Northwest Science, 92(2), 119. https://doi.org/10.3955/046.092.0205

Sheffield CS, Ratti C, Packer L, Griswold T 2011. Leafcutter and mason bees of the genus Megachile Latreille (Hymenoptera: Megachilidae) in Canada and Alaska. Canadian Journal of Arthropod Identification No. 18.

Willmer, P. (2012). Ecology: Pollinator-Plant Synchrony Tested by Climate Change. Current Biology, 22(4), R131-R132.

Winfree, R., Williams, N., Gaines, H., Ascher, J., \& Kremen, C. 2008. Wild bee pollinators provide the majority of crop visitation across land-use gradients in New Jersey and Pennsylvania, USA. Journal of Applied Ecology, 45(3), 793-802. 